\title{
In vitro chemo-preventative activity of Crotalaria agatiflora subspecies agatiflora Schweinf
}

Karlien Le Roux ${ }^{\text {a }}$, Ahmed A. Hussein ${ }^{\text {a,b }}$, Namrita Lall ${ }^{\text {a,\# }}$

Keywords: Crotalaria, Cytotoxicity, Radical scavenger, Flow cytometry, Cancer

\begin{abstract}
Ethnopharmacological relevance: Crotalaria species have been widely used in Chinese traditional medicine to treat several types of internal cancers. Crotalaria agatiflora is used as a medicinal plant in several African countries for the treatment of bacterial and viral infections as well as for cancer.
\end{abstract}

Materials and methods: Water and ethanol extracts of the leaves of C. agatiflora were evaluated for cytotoxcity on four cancerous and one noncancerous cell lines, using XTT (Sodium 3' - [1(phenyl amino-carbonyl)-3,4-tetrazolium]-bis-[4-methoxy-6-nitro) benzene sulfonic acid hydrate) colorimetric assay. Antioxidant activity was determined using DPPH (1,1-Diphenyl-2-picryl hydrazyl). Light microscopy (eosin and hematozylin staining) and flow cytometry (Annexin-V and propidium iodide) were used to evaluate the mechanism of action of the ethanol extract and one of the isolated compounds.

Results: The $50 \%$ inhibitory concentration $\left(\mathrm{IC}_{50}\right)$ of the ethanol extract was found to be 73.9 $\mu \mathrm{g} / \mathrm{mL}$ against leukemic U-937 cells. Good antioxidant activity $\left(\mathrm{IC}_{50}=18.89 \mu \mathrm{g} / \mathrm{mL}\right)$ of the ethanol extract indicated the potential of $C$. agatiflora as chemo-preventative supplement. A bioassay guided fractionation of the ethanol extract led to the isolation of two pure compounds, namely madurensine and doronenine. Madurensine and doronenine showed moderate cytotoxicity on cancerous U-937 cells ( $\mathrm{IC}_{50}$ values: 47.97 and $29.57 \mathrm{M}$ respectively). The crude extract treated U-937 cells showed definite signs of cell death during light microscopic investigation, while little apoptosis $(10-20 \%)$ and necrosis $(<2 \%)$ were detected in cells treated with the extract or madurensine.

Conclusions: The results indicated that C. agatiflora possesses potential chemopreventative and therapeutic properties. The exact mechanism of action should still be determined in future studies. It is hypothesised that the ethanolic extract as well as madurensine induces autophagy, which in prolonged circumstances may lead to autophagic cell death. 


\section{Introduction}

Crotalaria L. is one of the largest genera in tropical Africa. The genus includes 690 species that are mainly situated in Africa and Madagascar (le Roux et al., 2009). Species have also been found in India, United States of America (USA) and China. African countries use Crotalaria species (aerial parts), such as Crotalaria caudate Welw. Ex. Baker, Crotalaria retusa L., Crotalaria emarginella Vatke. and Crotalaria mesopontica Taub. for treating several types of bacterial and viral infections as well as for wound healing and for the treatment of skin conditions (Vlietinck et al., 1995, Bahar et al., 2006, Maregesi et al., 2007).

Similar uses of the genus are found in India, where the flowers are used to treat eczema and the leaves are placed on cuts to aid the healing process (Ram et al., 2004). Unspecified species of the genus are being used traditionally as decoctions in Ecuador to treat cancer (Tene et al., 2007). In the USA, Crotalaria pumila Ortega (aerial parts) is used to treat yellow fever and skin rashes (Adonizio et al., 2006). All plant parts of Crotalaria sessiliflora Vatke., Crotalaria assamica Benth. and Crotalaria ferruginea are being used traditionally in China to treat cancer (Graham et al., 2000). Aerial parts of Crotalaria agatiflora Schweinf. are used in Kenya for the treatment of ortitis media, a bacterial infection of ears, as well as for treating sexually transmitted diseases (Njoroge and Bussmann, 2006 and Njoroge et al., 2004). Researchers had found that this species relieved spasms in dogs, found to be a good relaxant and lowered blood pressure during treatment (Sharma et al., 1967). Due to the variety of biological activity of the genus most importantly being anti-cancer activity, it was decided to focus investigations on Crotalaria agatiflora subspp. agatiflora for its cytotoxic activity. Between 19 and 35\% of cancer-related mortalities are associated with nutritional factors (Russo, 2007 and WHO, 2008) and thus the cancer preventative activity was also investigated. The aims of the study were to determine the chemo-preventative (anti-cancer and cancer preventative) activity of Crotalaria agatiflora subspp. agatiflora. In the present study the bioactive principles of the extract were also identified and the mechanism of action of selected samples was investigated.

\section{Materials and methods}

\subsection{Chemicals and reagents}

All cell lines, media, trypsin-EDTA, fetal bovine serum (FBS) and antibiotics (penicillin, streptomycin and fungizone) were supplied by Highveld Biological (Pty) Ltd. (Modderfontein, Johannesburg, RSA). All plastic consumables used for culturing and analysis were supplied 
through Separations (Pty) Ltd. (Randburg, Johannesburg, RSA). Vanillin, sephadex, Bouin's fixative, haematoxylin, eosin and xylene were of analytical grade and supplied by Sigma-Aldrich (St. Louis, MO, USA). Solvents, silica and TLC plates were purchased from Merck (Germany). BD Biosciences’ Annexin-V-FITC apoptosis kit was purchased from BDBiosciences.

\subsection{Methods:}

\subsubsection{Plant material}

Crotalaria agatiflora subsp. agatiflora leaves were collected in Pretoria, South Africa during February 2009. The plant material was identified by Ms. Magda Nel at the University of Pretoria, and voucher specimen (PRU 096454) was deposited in the Schweickerdt Herbarium (PRU), Pretoria, South Africa.

\subsubsection{Extraction}

Air dried leaves were mechanically separated. Three different leaf extracts were prepared i.e. decoction, infusion and ethanolic. The air dried leaves of Crotalaria agatiflora subspp. agatiflora were homoginized with distilled water and extracted for $24 \mathrm{~h}$ twice. The menstruum was freeze dried to yield a brown powder. For the infusion powdered leaves and a vacuum rotary evaporator (water bath $80^{\circ} \mathrm{C}$ ) were used for extraction (15 minutes). The menstruum was freeze dried to yield an orange powder. Crotalaria agatiflora leaves were exhaustively extracted with distilled ethanol, the menstruum filtered and concentrated under reduced pressure with a vacuum rotary evaporator (Buchi) (Rahman and Kang, 2009). The plant extracts were stored in the cold room $\left(0^{\circ} \mathrm{C}\right)$.

\subsubsection{Cell cultures}

Cells were maintained in culture flasks in complete medium, supplemented with $10 \%$ heatinactivated FBS and antibiotic cocktail $(100 \mathrm{U} / \mathrm{mL}$ penicillin, $100 \mu \mathrm{g} / \mathrm{mL}$ streptomycin and 250 $\mu \mathrm{g} / \mathrm{L}$ fungizone). Cells were grown and maintained in a humidified atmosphere at $37^{\circ} \mathrm{C}$ and $5 \%$ $\mathrm{CO}_{2}$.

\subsubsection{Cytotoxicity of extracts using XTT kit}

Cytotoxicity was measured by the XTT method using the Cell Proliferation Kit II as described by the method of Zheng et al. (2001). Briefly, cells (100 $\mu$ l) were seeded (concentration $1 \times 10^{5}$ cells $/ \mathrm{mL}$ ) into a microtitre plate and incubated for $24 \mathrm{~h}$ to allow the cells to attach. Samples were diluted $(1.563-400 \mu \mathrm{g} / \mathrm{ml})$, added to the plates and incubated for $72 \mathrm{~h}$. The positive drug control, actinomycin D was included. After $72 \mathrm{~h}$ incubation XTT was added at a final concentration of 0.3 $\mathrm{mg} / \mathrm{ml}$ and incubated for 2-3 hours. Absorbance of the developed colour was 
spectrophotometrically quantified using a multi-well plate reader, which measured the optical density at $450 \mathrm{~nm}$ with a reference wavelength of $690 \mathrm{~nm}$. The samples were tested in triplicate. The inhibitory concentration of $50 \%$ of the cell population ( $\mathrm{IC}_{50}$ values) were defined as the concentration of the sample at which absorbance was reduced by $50 \%$. The results were statistically analyzed with GraphPad Prism 4 software. The selectivity index (SI) of the extract was defined as the ratio of cytotoxicity on Vero cells to cancerous cells (Mena-Rejon et al., 2008).

\subsubsection{Antioxidant activity - DPPH radical scavenging}

The method of du Toit et al. (2001) was followed with some modifications. Briefly the samples were prepared as stock solutions of $10 \mathrm{mg} / \mathrm{mL}$. The concentrations tested for the plant extracts ranged between $3.906-500 \mu \mathrm{g} / \mathrm{mL}$ and the concentration of vitamin $\mathrm{C}$ between $0.781-100 \mu \mathrm{g} / \mathrm{mL}$. All the samples were prepared in triplicate. Ninety microlitres DPPH $(0.04 \mathrm{mg} / \mathrm{mL})$ was added to all of the wells, except for the colour control in which the DPPH was substituted with distilled water. The plates were left in the dark to develop at room temperature for 30 minutes. The radical scavenger capability of the samples were determined by using a multi-well plate reader to measure the decolouration of DPPH at $515 \mathrm{~nm}$, using $\mathrm{KC}$ Junior software. The $\mathrm{IC}_{50}$ values for each sample were determined by using GraphPad Prism 4 software.

\subsubsection{Isolation of bioactive compounds using bioassay-guided fractionation}

A total of $50 \mathrm{~g}$ ethanolic extract was subjected to liquid-liquid partition. The extract was dissolved in $80 \%$ methanol. The filtrate was acidified using $5 \% \mathrm{HCl}$, shaken twice with dichloromethane (DCM) and then ammonia solution $\left(\mathrm{NH}_{4} \mathrm{OH}\right)$ was added to the aqueous solution till $\mathrm{pH} \sim 12.0$. The aqueous solution was shaken twice again with DCM after which the DCM fractions were concentrated using a rotavapor. Sixteen grams alkaloidal fraction was subjected to silica gel column chromatography (CC, size $10 \times 20 \mathrm{~cm})$ using DCM/MeOH of increasing polarity $(0 \%$ $10 \%)$. A total of 40 fractions were collected and pooled based on their thin layer chromatography (TLC) profile ( 8 fractions). Based on the cytotoxicity results, fraction 3 and 4 were selected for the identification of bioactive principles. Fraction 3 was subjected to sephadex column chromatography $(\mathrm{CC}, 4 \times 15 \mathrm{~cm})$ using EtOH as an eluent. Collected fractions were spotted on TLC plates using $\mathrm{CHCl}_{3}$ : $\mathrm{MeOH}: \mathrm{NH}_{4}(95: 5: 0.1)$ as eluent. After the TLC plates were analyzed, similar fractions were combined which resulted in three major subfractions. Subfraction 3.3 contained only three major bands on the TLC plate. Subfraction 3.3 was further purified using preparative TLC. Thirty milligram of Subfraction 3.3 was spotted on three TLC plates and developed using $\mathrm{CHCl}_{3}: \mathrm{MeOH}: \mathrm{NH}_{4} \mathrm{OH}$ (95: 5: 0.1) as eluent. Three different bands were observed under UV which was scratched off the aluminium plates using a blade. The silica gel 
powder was eluted twice with distilled ethyl acetate and three times with distilled $\mathrm{MeOH}$. The structural elucidation of isolated compound (only Band III, $24 \mathrm{mg}$ ) was identified by physical (mp. $\left.[\alpha]_{\mathrm{D}}\right)$ and spectroscopic $\left({ }^{1} \mathrm{H}\right.$ and ${ }^{13} \mathrm{C}$ NMR) data (Compound I). Fraction 4 yielded a white crystalline compound which was washed first with ethyl acetate: hexane (50:50), followed by methanol (100\%). The precipitated crystals were developed on TLC and showed one clear spot; hence the sample was subjected to NMR analysis (Compound II). Cytotoxicity was carried out against U-937 and Vero cells after which antioxidant activity was also conducted as previously described, with the exception that the compounds were tested between $0.781-100 \mu \mathrm{g} / \mathrm{mL}$.

\subsubsection{Cell morphology - light microscopy (haematoxylin and eosin staining)}

Leukemic U-937 cells were exposed to $73.9 \mu \mathrm{g} / \mathrm{mL}\left(\mathrm{IC}_{50}\right)$ and $147.8 \mu \mathrm{g} / \mathrm{mL}\left(2 \mathrm{IC}_{50}\right)$. Vero cells were exposed to ethanol extract at $73.9 \mu \mathrm{g} / \mathrm{mL}\left(\mathrm{IC}_{50}\right)$ and $147.8 \mu \mathrm{g} / \mathrm{mL}\left(2 \mathrm{IC}_{50}\right)$ and additionally to $352.4 \mu \mathrm{g} / \mathrm{mL}\left(\mathrm{IC}_{50}\right)$ and $704.8 \mu \mathrm{g} / \mathrm{mL}\left(2 \mathrm{IC}_{50}\right)$. Madurensine, one of the isolated compounds, was retained for more crucial analysis. U-937 cells are suspension cells and therefore it was necessary to manipulate the cells to adhere to the coverslips. U-937 cells were washed three times with buffer to and resuspended in complete medium lacking FBS. This treatment allowed U-937 cells to adhere to the coverslip. Exponentially growing U-937 and Vero cells were seeded at one million and 250,000 cells per well respectively on sterilized coverslips. After $24 \mathrm{~h}$ incubation $\left(37^{\circ} \mathrm{C}, 5 \% \mathrm{CO}_{2}\right)$, U-937 cells were exposed to $73.9 \mu \mathrm{g} / \mathrm{mL}\left(\mathrm{IC}_{50}\right)$ and $147.8 \mu \mathrm{g} / \mathrm{mL}\left(2 \mathrm{IC}_{50}\right)$ of ethanolic extract including vehicle-treated control $(0.74 \%)$, actinomycin D $(2.51 \mathrm{mM})$ and cells propagated in growth medium. Vero cells were exposed to $73.9 \mu \mathrm{g} / \mathrm{mL}$ ( $\mathrm{IC}_{50}$ of U-937 cells) and $147.8 \mu \mathrm{g} / \mathrm{mL}$ (2IC $\mathrm{IC}_{50}$ of $\mathrm{U}-937$ cells), $352.4 \mu \mathrm{g} / \mathrm{mL}\left(\mathrm{IC}_{50}\right)$ and $704.8 \mu \mathrm{g} / \mathrm{mL}\left(2 \mathrm{IC}_{50}\right)$ of ethanolic extract including vehicletreated control $(3.5 \%)$, actinomycin D $(100.43 \mathrm{mM})$ and cells propagated in growth medium. The cells were incubated for $72 \mathrm{~h}$ at $37^{\circ} \mathrm{C}$. Cells were fixed in Bouin's fixative (60 minutes) and stained using standard haematoxylin and eosin staining procedures (Stander et al., 2009). The cells were investigated using Nikon Stereo Light microscope equipped 1.4 Apo oil lense (Microscopy Unit, University of Pretoria). The magnification was x 1000.

\subsubsection{Apoptosis detection - flow cytometry (Annexin-V and Propidium iodide staining)}

Exponentially growing U-937 cells were seeded at $0.5 \times 10^{6}$ cells per $25 \mathrm{~cm}^{2}$ flask. Cells were exposed to $73.9 \mu \mathrm{g} / \mathrm{mL}\left(\mathrm{IC}_{50}\right)$ and $147.8 \mu \mathrm{g} / \mathrm{mL}\left(2 \mathrm{IC}_{50}\right)$ of the ethanolic extract and exposed to 47.97 M madurensine respectively and incubated for $72 \mathrm{~h}$. The analysis included vehicle-treated control $(0.74 \%)$ and actinomycin D $(0.25 \mathrm{M})$ treated cells. One million cells were double-stained with annexin- $\mathrm{V}$ and propodium iodide, according to the manufacturer's instructions. Annexin- $\mathrm{V}$ and propidium iodide fluorescence were measured with a BD FACS Aria flow cytometer (BD 
Biosciences) equipped with an air-cooled argon laser excited at 488nm (Stander el al, 2009) at the Department of Biochemistry, University of Pretoria, with guidance from Wayne Barnes. The annexin-V signal was detected using the 530/30 BP filter and the PI signal using 585/42 BP filter. Data from at least 10,000 cells were analyzed with BD FACS Diva Software Version 6.1 (BD Biosciences) (Kang et al., 2009).

\section{Results}

\subsection{Cytotoxicity of crude extracts}

The National Cancer Institute of the United States of America (2010) suggested that IC $_{50}$ values below $20 \mu \mathrm{g} / \mathrm{mL}$ was active, while many authors have suggested extracts have anti-cancer potential when the $\mathrm{IC}_{50}$ value is below $100 \mu \mathrm{g} / \mathrm{mL}$. Infusion and decoction extracts were not active, with $\mathrm{IC}_{50}$ values higher than $400 \mu \mathrm{g} / \mathrm{mL}$. The ethanol extract was the most active with varying $\mathrm{IC}_{50}$ values between 74.94 and $243.3 \mu \mathrm{g} / \mathrm{mL}$. U-937 cells were the most sensitive cancerous cells treated with the ethanolic extract and positive control. It was also found that the ethanol extract was the most selective comparing IC $_{50}$ values of U-937 and Vero cells. The selectivity index (SI) of extracts was defined as the ratio of cytotoxicity on normal healthy cells to cancerous cells. In general it is considered that the biological efficacy is not due to cytotoxicity when the SI value is $\geq 10$ (MenaRejon et al, 2008). The Infusion and Decoction extracts didn't show any preference to any of the cell lines. The ethanolic extract had the best selectivity values as compared to all of the samples tested with U-937 (4.77), SNO (3.11), HeLa (2.30) and MCF-7 (1.45), excluding actinomycin D that had an SI value of 40 using U-937 cells. Actinomycin D had SI values lower than 1.2 on all the rest of the cancerous cells. The pure compound's toxicity is not due to cytotoxicity, but rather due to another type of mechanism, such as the induction of apoptosis by forming stable complexes with DNA and interfering with DNA-dependent RNA synthesis.

Table 1: Cytotoxicity of extracts

\begin{tabular}{lccccc}
\hline \multicolumn{1}{c}{ Sample / Cell } & \multicolumn{5}{c}{ IC $_{\mathbf{5 0}}{ }^{\mathbf{a}}(\boldsymbol{\mu g} / \mathbf{m L})$} \\
\cline { 2 - 6 } \multicolumn{1}{c}{ line } & $\mathbf{U - 9 3 7}$ & HeLa & SNO & MCF-7 & Vero \\
\hline Infusion & $>400$ & $>400$ & $>400$ & $>400$ & $>400$ \\
Decoction & $>400$ & $>400$ & $>400$ & $>400$ & $>400$ \\
Ethanol & $73.94 \pm 1.06$ & $153.3 \pm 0.75$ & $113.2 \pm 2.43$ & $243.3 \pm 6.2$ & $352.4 \pm 5.9$ \\
& & $\mathbf{9 4 . 1 6} \pm \mathbf{1 . 2 5}$ & $\mathbf{9 0 . 3 9} \pm \mathbf{5 . 0}$ & $\mathbf{1 5 0 . 6 5} \pm$ & $\mathbf{1 0 0 . 4 3} \pm$ \\
Actinomycin $\mathbf{D}^{\mathbf{b}}$ & $\mathbf{2 . 5 1} \mathbf{0 . 0 6} \mathbf{~ m M}$ & $\mathbf{m M}$ & $\mathbf{m M}$ & $\mathbf{1 . 2 5} \mathbf{~} \mathbf{~ M}$ & $\mathbf{3 6 . 4 1} \mathbf{~} \mathbf{M}$ \\
\hline
\end{tabular}

${ }^{\mathrm{a}}$ Fifty percent inhibitory concentration

${ }^{\mathrm{b}}$ Positive drug control 


\subsection{Determination of antioxidant activity}

All three extracts showed dose-dependent responses. Both water extracts showed nearly identical capacity of DPPH reduction, while the ethanolic extract was the most effective in free radical scavenging. All three samples demonstrated dose-dependent responses (Fig. 1). The $\mathrm{IC}_{50}$ values were as follows: Ethanolic $18.89 \pm 0.305 \mu \mathrm{g} / \mathrm{mL}$, Decoction $27.31 \pm 1.59 \mu \mathrm{g} / \mathrm{mL}$ and Infusion $29.63 \pm 1.59 \mu \mathrm{g} / \mathrm{mL}$. Vitamin $\mathrm{C}$, the positive control had an $\mathrm{IC}_{50}$ of $240.94 \pm 0.18 \mathrm{mM}$.

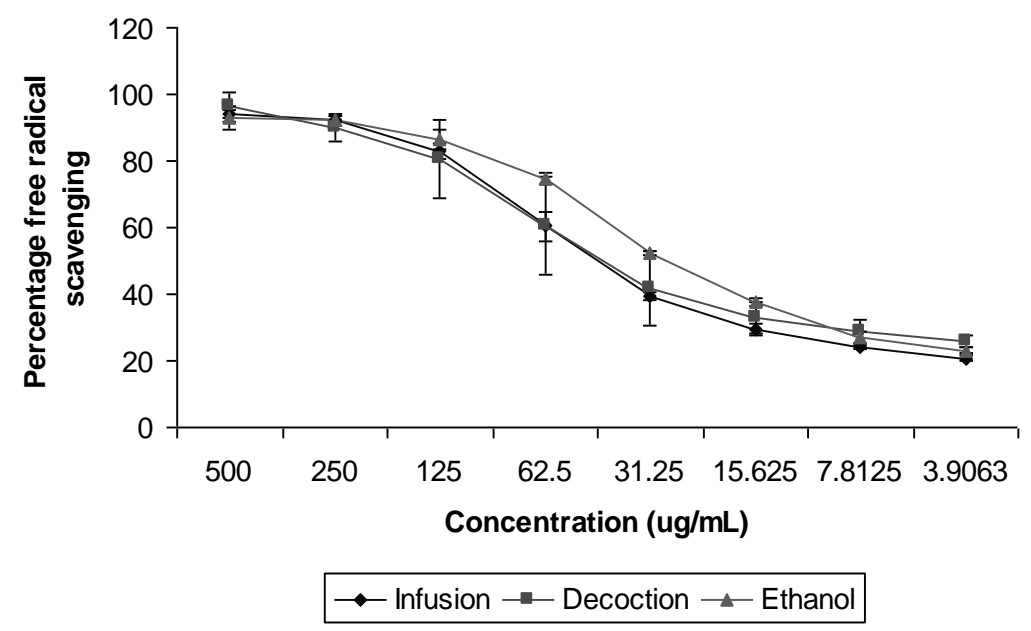

Fig. 1 Anti-oxidant activity of extracts

\subsection{Isolated compounds via bioassay-guided fractionation}

Two compounds were isolated, both belonging to pyrrolizidine alkaloids. Compound 1 was isolated from the total alkaloidal fraction using silica column chromatography. The compound was identified as doronenine (1,2 - Dihydro bulgarsenine), based on NMR data $\left({ }^{1} \mathrm{H}\right.$ and $\left.{ }^{13} \mathrm{C}\right)$. The NMR data for the compound was similar with those reported for the same compound in literature (Roder et al., 1980). This is the first report of doronenine being isolated from Crotalaria agatiflora subspp. agatiflora. Compound II was isolated from Fraction 4 and identified as madurensine based on spectroscopic analysis reported by previous researchers (Verdoorn and Van Wyk, 1992). Madurensine had been previously identified in Crotalaria agatiflora, Crotalaria rosenii, Crotalaria madurensis, Crotalaria laburnifolia and Crotalaria agatiflora subsp imperialis (Atal and Kapur, 1966, Abegaz et al., 1987 Asres et al., 2004 and Flores et al., 2009) and was found together with trans-anacrotine to be the only alkaloids in the seeds of Crotalaria capensis (Verdoorn and Van Wyk, 1992) (Fig. 2). 

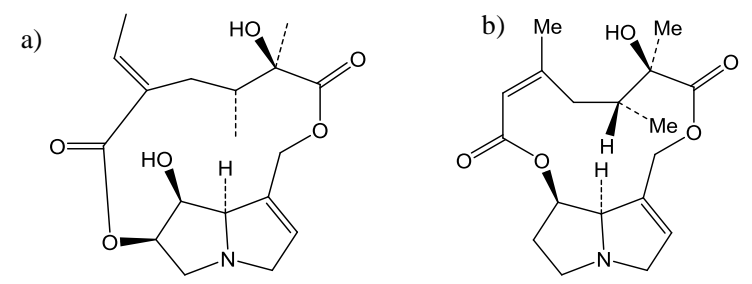

Fig. 2 Chemical structures of madurensine (a) and doronenine (b)

Madurensine had an $\mathrm{IC}_{50}$ value of $47.97 \pm 6.3 \mathrm{M}$, while doronenine had an $\mathrm{IC}_{50}$ value of $29.57 \pm$ $0.916 \mathrm{M}$ against U-937 cells (Fig. 3a). Actinomycin D had an $\mathrm{IC}_{50}$ value of $2.51 \pm 0.063 \mathrm{mM}$. Madurensine had been screened for anti-cancer activity by the National Cancer Institute (NCI). Different yeast stains such as mlh1 rad18, bub3, cln2 rad14, sgs1 mgt1, mec2-1 and rad50 were used to test the compound's anti-cancer activity. The bioassay is based on growth inhibition of yeast strains with defined genetic alterations. Compound treatments which inhibited the growth of the yeast by $70 \%$ were considered active. All strains tested negative for anti-cancer activity (PubChem, 2009). To our knowledge no data is available for any biological activity of doronenine. Vero cells were less susceptible to the influence of doronenine and madurensine as compared to that of the compounds on U-937 cells (Fig. 3b). Madurensine and doronenine exhibited an estimated $\mathrm{IC}_{50}$ value of $7443.69 \pm 1.17$ and $946.79 \pm 0.58 \mathrm{M}$ respectively (calculated with GraphPad Prism 4). Actinomycin D had an $\mathrm{IC}_{50}$ value of $100.43 \pm 36.41 \mathrm{mM}$. Madurensine had a selectivity index (SI) value of 155.2 while doronenine had an SI value of 32. Although doronenine was more active than madurensine against U-937 cells, it was less selectively cytotoxic. Both compounds showed weak DPPH scavenging potential at the highest concentration tested. Both these compounds' $\mathrm{IC}_{50}$ values were higher than $100 \mu \mathrm{g} / \mathrm{mL}$.

a)

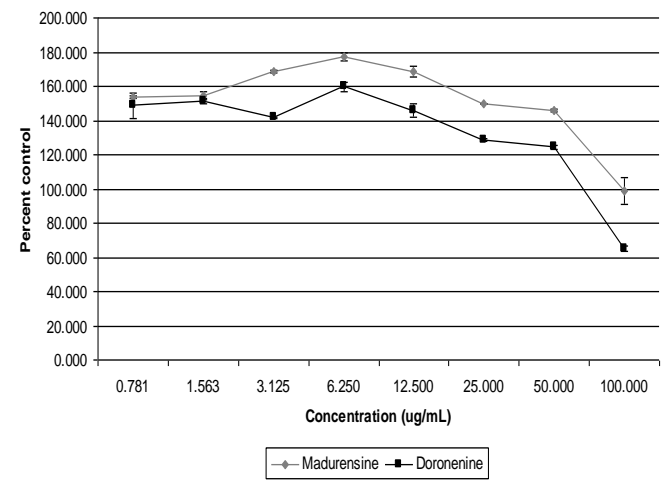

b)

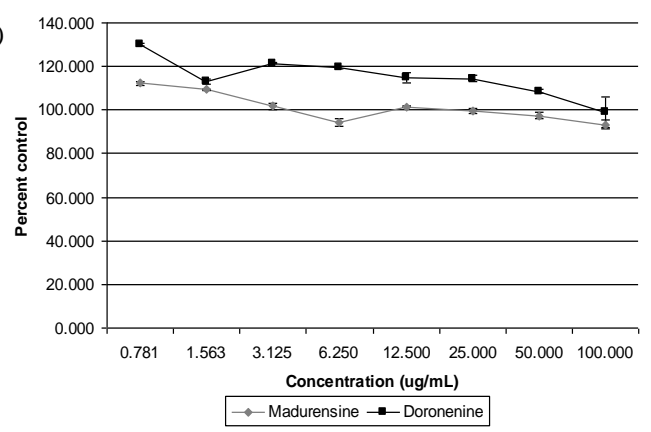

Fig. 3 Dose-response curves of madurensine and doronenine on U-937 cells (a) and Vero cells (b) 


\subsection{Light microscopy}

\section{$3.4 .1 \quad U-937$ cells}

Large multiple nuclii were observed in the present study (Fig. 4a). The cells had intact cell membranes and large amounts of cytoplasm. Vehicle control cells were viable and still able to grow (Fig. 4b). Actinomycin D (2.51 mM) showed severe signs of cell death (Fig. 4c) and the density of cells decreased as compared to the untreated cells which was an indication that cells detached during incubation. Nuclear material of treated cells, chromatin condensation and fragments were visible. Crotalaria agatiflora treated U-937 cells revealed an increase in morphological features of cell death in a dose-dependent manner, which included decreased cell density, hypercondensed chromatin, apoptotic bodies and shrunken cells (Fig. 4d and e). Those features are characteristic of apoptosis and autophagy.
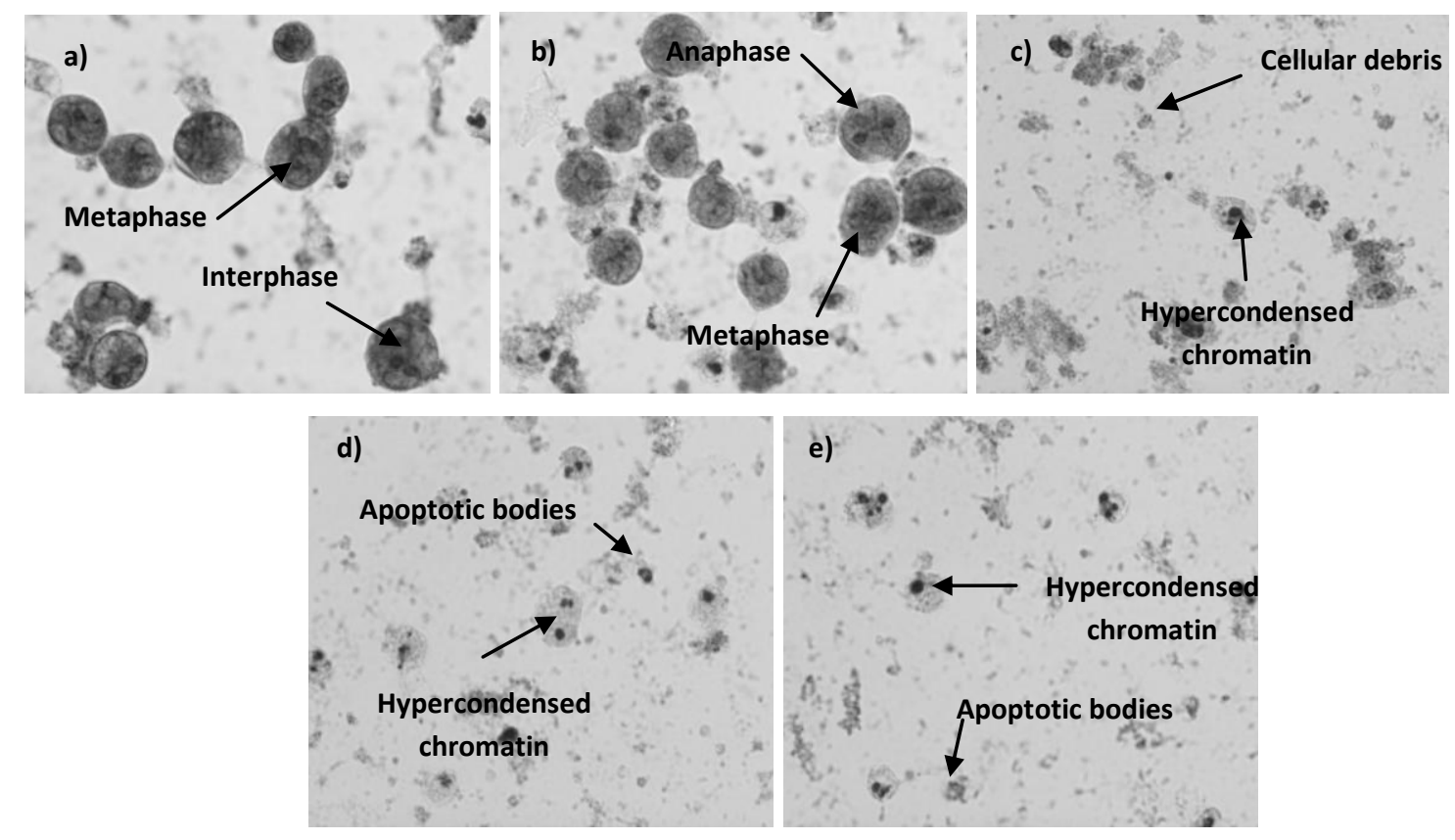

Fig. 4 Haematoxylin and eosin staining of U-937 cells, medium control (a), DMSO (b), actinomycin D (c), 73.9 $\mu \mathrm{g} / \mathrm{mL}$ extract treated (d) and $147.8 \mu \mathrm{g} / \mathrm{mL}$ extract (e) treated cells.

\subsubsection{Vero cells}

Vehicle control cells (3.5\%) were viable (Fig. 5b) as compared to untreated Vero cells (Fig. 5a). Actinomycin D (100.43 mM) showed severe signs of cell death (Fig. 5c). Non-cancerous Vero cells revealed minimal signs of cell death when the cells were treated with $73.9 \mu \mathrm{g} / \mathrm{mL}$ and 147.8 $\mu \mathrm{g} / \mathrm{mL}\left(\mathrm{IC}_{50}\right.$ and twice the of $\mathrm{IC}_{50}$ of U-937 cells) of the ethanolic extract (Fig. $5 \mathrm{~d}$ and 5e). Cells treated with $352.4 \mu \mathrm{g} / \mathrm{mL}$ and $704.8 \mu \mathrm{g} / \mathrm{mL}$ of the ethanolic extract showed dose-dependent signs of 
cell death. Those signs included reduction in cell size and hypercondensed chromatin (Fig. $5 \mathrm{f}$ and $5 \mathrm{~g})$.
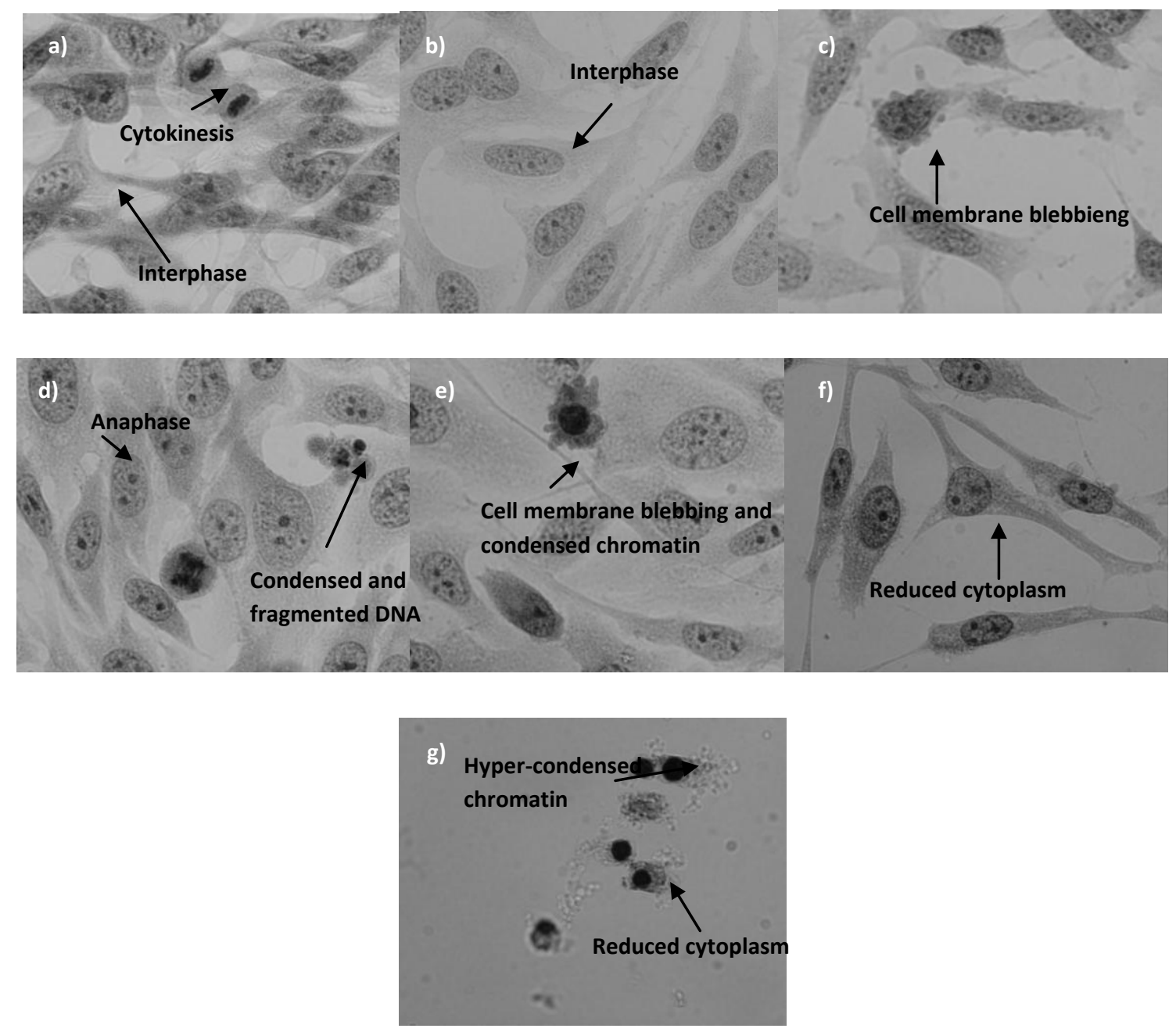

Fig. 5 Haematoxylin and eosin staining of Vero cells in medium (a), DMSO (b), actinomycin D (c), 73.9 $\mu \mathrm{g} / \mathrm{mL}$ extract (d) $147.8 \mu \mathrm{g} / \mathrm{mL}$ extract (e), 352.4 $\mu \mathrm{g} / \mathrm{mL}$ extract (f) and $708.4 \mu \mathrm{g} / \mathrm{mL}$ extract treated cells (g)

\subsubsection{Apoptosis detection analysis after $72 \mathrm{~h}$ incubation}

Annexin-V can be detected in both early and late stages of apoptosis, while PI intercalates DNA during late stages of apoptosis and necrosis. Viable cells were negative for both Annexin-V and PI (lower left quadrant), early apoptotic cells were positive for Annexin-V and negative for PI (lower right quadrant), late apoptotic cells displayed both positive Annexin-V and PI binding (upper right quadrant) and necrotic cells were positive for PI binding and negative for Annexin-V (upper left quadrant). After treatment for 72 hours the percentages of combined early and late induced apoptosis by $73.9 \mu \mathrm{g} / \mathrm{mL}$ and $147.8 \mu \mathrm{g} / \mathrm{mL}$ of the crude ethanolic extract and $47.97 \mathrm{M}$ madurensine, 
were $6.7 \%, 17.6 \%$ and $3.5 \%$ respectively, while vehicle treated $(0.74 \%)$ apoptotic cells was $2.3 \%$. Apoptosis was thus insignificantly induced in all samples tested. These results suggested that the anti-proliferation effect of the samples were mediated insignificantly by the induction of apoptosis (Fig. 6).
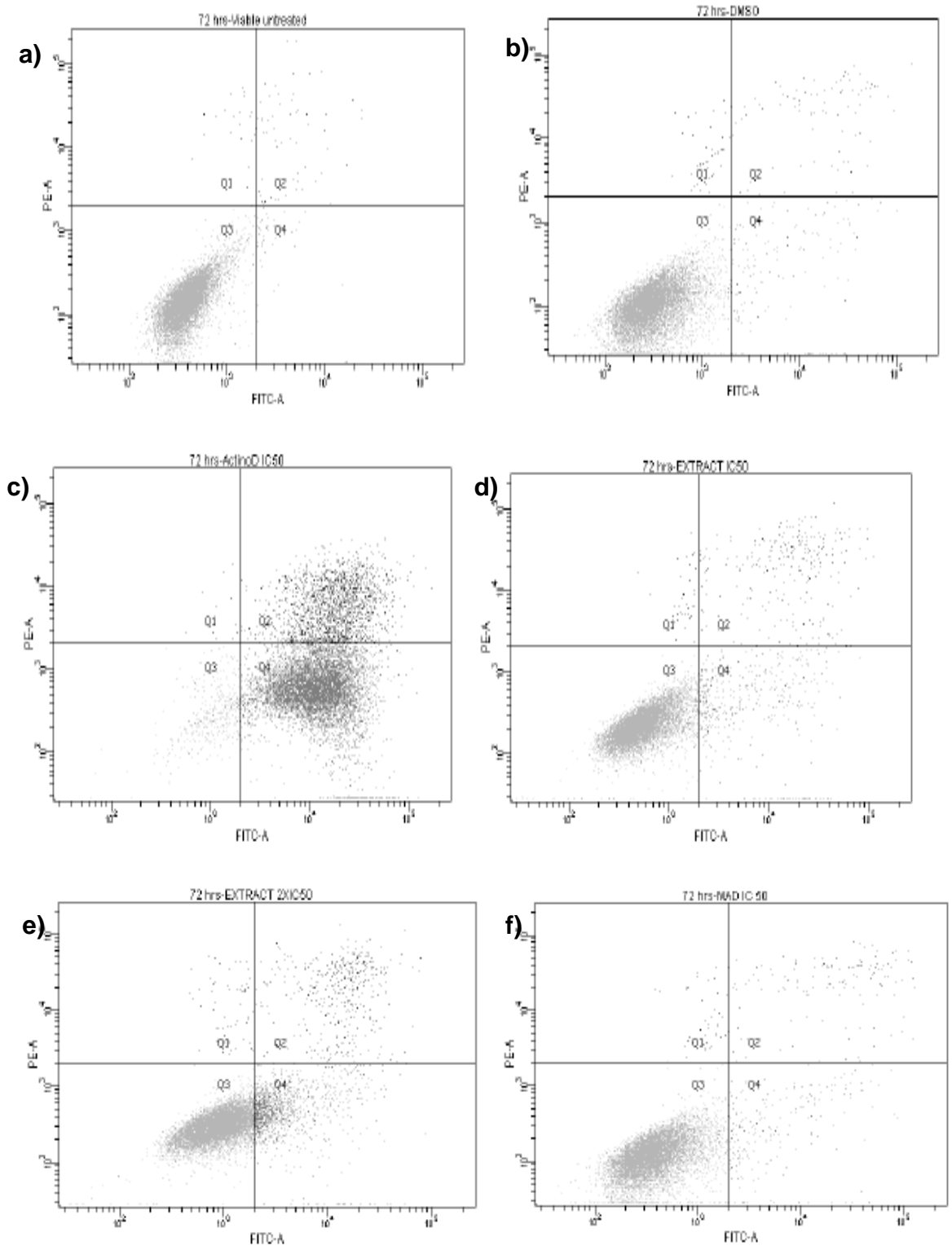

Fig.6 Annexin-V (FITC) versus Propidium iodide (PE) dot plots of: a) untreated U-937 cells, b) DMSO, c) actinomycin D, d) $73.9 \mu \mathrm{g} / \mathrm{mL}$ extract, e) $147.8 \mu \mathrm{g} / \mathrm{mL}$ extract and f) madurensine treated cells 


\section{Discussion}

By using the $\mathrm{IC}_{50}$ values obtained for the ethanolic extract it can be said that the survival rate of the cells was MCF-7 > HeLa > SNO > U-937. The Vero cells were perceived as normal healthy cells, although these cells have been transformed to immortalize them. Overall the water extracts of Crotalaria agatiflora performed poorly during the determination of cytotoxicity having similar $\mathrm{IC}_{50}$ values, being higher than $400 \mu \mathrm{g} / \mathrm{mL}$. This inability of water extracts to kill cancerous cells at low concentrations may be due to the type of compounds extracted during the extraction process.

Water is a polar molecule which in theory will then be able to be used when polar compounds are being extracted, such as sugars, amino acids and glycosides (Houghton, 2008). At the end it was determined that using water as extraction solvent for Crotalaria leaves will have poor anti-cancer activity. These findings are in contrast with the traditional uses of Crotalaria spp. in Ecuador for the use of fresh leaves that are infused and used to treat cancers (Tene et al., 2007). In China a variety of Crotalaria spp. are used for treating cancers. Unfortunately little information for preparation of extracts for treatments had been documented. Ethanol is a very good extractant, thus it can be postulated that alkaloids and pyrrolizidine alkaloids may have caused the cytotoxicity of the tested cells. Crotalaria is known to have high concentrations of alkaloids (Graham et al., 2000). The ethanol extract had the highest SI value on U-937 cells, as compared to the other extracts and against the other cell lines.

In previous studies conducted on Bidens pilosa it was found that the ethanol extract had an $\mathrm{IC}_{50}$ value of $80.93 \mu \mathrm{g} / \mathrm{mL}$ using the DPPH assay (Chiang et al., 2004). Many other crude extracts had been tested previously for their antioxidant activity, as reported briefly by Drewes et al. (2008). It was found that Hypoxis hemerocallidea extract; another traditionally used plant of South Africa had an $\mathrm{IC}_{50}$ value of $75 \mu \mathrm{g} / \mathrm{mL}$ when it was determined by TBA assay. It has been reported that olive leaf oil has an $\mathrm{IC}_{50}$ value of more than $30 \mu \mathrm{g} / \mathrm{mL}$, while green tea has an $\mathrm{IC}_{50}$ value of $16 \mu \mathrm{g} / \mathrm{mL}$. Comparing all of the above mentioned results with Crotalaria agatiflora, it is clear that Crotalaria agatiflora had better antioxidant activity than Bidens pilosa and Hypoxis. hemerocallidea. On the other hand the water extracts of Crotalaria agatiflora had similar antioxidant potential as olive leaf extracts, while the ethanol extract had similar antioxidant activity as compared to green tea. Most chemotherapy drugs are inducing the production of reactive oxygen species within the human body, thus forming an important part of the mechanism of action of many of these drugs such as doxorubicin. Thus the question should be asked whether plant extracts could have the ability to be cytotoxic and at the same time have protective properties such as good antioxidant potential. 
When cancerous U-937 cells and non-cancerous Vero cells morphological changes were compared, we found that at $73.9 \mu \mathrm{g} / \mathrm{mL}$ the U-937 cells were much more susceptible and sensitive to the treatments compared to the same concentration on Vero cells. As observed by Chinkwo (2005), who explored cervical carcinoma (Caski) and Chinese hamster ovary (CHO) cells treated with Sutherlandia frutescens (popular anti-cancer plant), the cells in the present study at the respective $\mathrm{IC}_{50}$ values had condensed nuclei and decreased amount of cytoplasm. Conclusions are in agreement with the conclusions made by Stander et al. (2009) who observed similar selectivity between cancerous breast adenocarcinoma (MCF-7) and non-cancerous epithelial mammary gland (MCF-12A) cells treated with aqueous extracts of Suderlandia. frutescens. In the present study, the affects of treatment were much more severe in U-937 cells and thus the mechanism of action was determined in U-937 cells. It should be mentioned that the results found with light microscopy was insufficient in determining the type of cell death, due to the fact that apoptosis and autophagy looks very similar in light microscopy investigations.

To demonstrate the mechanism of cell death, the effect of the ethanolic extract was tested at 73.9 $\mu \mathrm{g} / \mathrm{mL}\left(\mathrm{IC}_{50}\right)$ and $147.8 \mu \mathrm{g} / \mathrm{mL}\left(2 \mathrm{IC}_{50}\right)$ and madurensine at $47.97 \mathrm{M}\left(\mathrm{IC}_{50}\right)$ to determine the percentage binding of Annexin-V-FITC and PI. After 72 hours, untreated cells were $98.8 \%$ unstained by Annexin-V and PI and thus viable, with only minute percentages of cells in stages of cell death which was similar to the findings observed by Stander et al. (2009) who explored MCF-7 cells during flow cytometric analysis. Viability obtained during the analysis of untreated MCF-7 cells was $91.4 \%$. The increased viability in the U-937 cells could be due to the fact that MCF-7 cells were trypsinized to detach the cells from the flask surfaces. During trypsinaztion cells can be damaged due to the nature of the enzyme trypsin. It was found that the viability $(97.3 \%)$ decreased slightly after $72 \mathrm{~h}$ incubation with $0.74 \%$ DMSO in the present study. This decrease was small but confirms that DMSO had negative effects on cell cultures. Actinomycin D induced apoptosis. This was in agreement with Stander et al. (2009), which found that $5.8 \%$ cells were viable after $0.25 \mathrm{M}$ actinomycin D treatment. Cells treated with different concentrations of Crotalaria agatiflora leaves' extract showed dose-dependent responses. The same scenario was seen when U-937 cells were treated with madurensine. Out of these results it is evident that cells' viability was not affected by the treatments and that little cell death via apoptosis and necrosis took place.

The results indicated that $C$. agatiflora possesses potential chemopreventative and therapeutic properties. The exact mechanism of action should still be determined in future studies. It is hypothesised that the ethanolic extract as well as madurensine induces autophagy, which in prolonged circumstances may lead to autophagic cell death. 


\section{Acknowledgements:}

The authors would like to acknowledge Wayne Barnes (Department of Biochemistry) and Andre Stander (Department of Physiology) from the University of Pretoria, for their guidance and technical support during the investigation.

\section{References}

Abegaz, B., Atnafu, G., Duddeck, G., Snatzke, G. 1987. Macrocyclic pyrrolizidine alkaloids of Crotalaria rosenii. Tetrahedron 43, 3263-3268.

Adonizio, A.L., Downum, K., Bennet, B.C., Mathee, K. 2006. Anti-quorum sensing activity of medicinal plants in southern Florida. J. Ethnopharmacol. 105, 427-435.

Asres, K., Sporer, F., Wink, M. 2004. Patterns of pyrrolizidine alkaloids in 12 Ethiopian Crotalaria species. Biochem. Syst. Ecol. 32, 915-930.

Atal, C, K., Kapur, K.K. 1966. A new pyrrolizidine aminoalcohol in alkaloids of Crotalaria species. Tetrahedron Lett. 6, 537-544.

Bahar, A., Al-Howiriny, T.A., Mossa, J.S. 2006. Crotalic acid and emarigellic acids: Two tripenes from Crotalaria emarginella and anti-inflammatory and anti-hepatoxic activity of crotalic acid. Phytochemistry 67, 956-964.

Chiang, Y-M., Chuang, D-Y., Wang, S-Y., Kuo, Y-H., Tsai, P-W., Shyur, L-F. 2004. Metabolite profiling and chemopreventative bioactivity of plant extracts from Bidens pilosa. J. Ethnopharmacol. 95, 409-419.

Chinkwo, K.A. 2005. Sutherlandia frutescens extracts can induce apoptosis in cultured carcinoma cells. J. Ethnopharmacol. 98, 163-170.

Dictionary of Natural Products. 2010. "Search engine.” [Online]. Available: http://www.dnp.chemnetbase.com [Cited 1 March 2010].

Drewes, S.E., Elliot, E., Khan, F., Dhlamini, J.T.B., Gcumisa, M.S.S. 2008. Hypoxis hemerocallidea - Not merely a cure for benign prostate hyperplasia. J. Ethnopharmacol. 119, 593-598.

Du Toit, R., Volsteedt, Y., Apostolides, Z. 2001. Comparison of the antioxidant content of fruits, vegetables and teas measured as vitamin $C$ equivalents. Toxicology 166, 63-69. 
Flores, A.S., de Azevedo Tozzi, A.M.G., Trigo, J.R. 2009. Pyrrolizidine alkaloid profiles in Crotalaria species from Brazil: Chemotaxonomic significance. Biochem. Syst. Ecol. 37, 459469.

Graham, J.G., Quinn, M.L., Fabricant, D.S., Farnsworth, N.R. 2000. Plants used against cancer an extension of the work of Jonathan Hartwell. J. Ethnopharmacol. 73, 347-377.

Ram, A., Bhakshu, M.D., Venkata Raju, R.R. 2004. In vitro antimicrobial activity of certain medicinal plants from Eastern Ghats, India, used for skin diseases. J. Ethnopharmacol. 90, 353357.

Le Roux, M.M., Van Wyk, B-E., Moteetee, A.N., Tilney, P.M. 2009. An evaluation of molecular and anatomical characters in the genus Crotalaria. S. Afr. J. Bot 75, 410.

Maregesi, S.M., Ngassapa, O.D., Pieters, L., Vlietinck, A.J. 2007. Ethnopharmacological survey of the Bunda district, Tanzania: Plants used to treat infectious diseases. J. Ethnopharmacol. 113, 457-470.

Mena-Rejon, G., Caamal-Fuentes, E., Cantillo-Ciau, Z., Cedillo-Rivera, R., Flores-Guido, J., MooPuc, R. 2008. In vitro cytotoxic activity of nine plants used in Mayan traditional medicine. J. Ethnopharmacol. doi: 10.1016/j.jep.2008.11.12.

Njoroge, G.N., Bussmann, R.W. 2006. Traditional management of ear, nose and throat (ENT) diseases in Central Kenya. J. Ethnobiol. Ethnomed. 2, 54-62.

Njoroge, N.G., Bussmann, R.W., Newton, B., Eric, L. and Ngumi, V.W. 2004. Utilization of weed species as sources of traditional medicines in Central Kenya. Lyonia (unpublished) 1-16.

[Online]. Available: www.lyonia.org .

PubChem. 2009. "BioActivity Analysis." [Online]. Available: http://www.pubchem.ncbi.nlm.nih.gov.innopac.up.az.za/assay [Cited 11 September 2009].

Raman, A., Kang, S.C. 2009. In vitro control of food-borne and food spoilage bacteria by essential oil and ethanol extracts of Lonicera japonica Thunb. Food Chem. 116, 670-675.

Roder, E., Wiedenfeld, H., Frisse, M. 1980. Pyrrolizdine alkaloide aus Senecio doronicum. Phytochemistry 19, 1275-1277.

Russo, G.L. 2007. Ins and outs of dietary phytochemicals in cancer chemoprevention. Biochem. Pharmacol. 74, 533-544. 
Sharma, M.L., Singh, G.B., Ghatak, B.J. 1967. Pharmacological investigations on Crotalaria agatiflara Scwienf. Indian J. Exp. Biol. 5, 149-150.

Stander, A., Marais, S., Stivaktas, V., Voster, C., Albrecht, C., Lottering, M-L., Joubert, A.M. 2009. In vitro effects of Sutherlandia frutescens water extracts on cell numbers, morphology, cell cycle progression and cell death in a tumorigenic and a non-tumorigenic epithelial breast cell line. J. Ethnopharmacol. 124, 45-60.

Tene, V., Malagon, O., Finzi, P.V., Vidari, G., Armijos, C., Zaragoza, T. 2007. An ethnobotanical survey of medicinal plants used in Loja and Zamora-Chinchipe, Ecuador. J. Ethnopharmacol. $111,63-81$.

Verdoorn, G.H., Van Wyk, B-E. 1992. Pyrrolizidine alkaloids from seeds of Crotalaria capensis. Phytochemistry 31, 369-371.

Vlietinck, A.J., Van Hoof, L., Totte, J., Lasure, A., Van den Berghe, D., Rwangabo, P.C., Mvukiyumwami, J. 1995. Screening of hundred Rwandese medicinal plants for anti-microbial and antiviral properties. J. Ethnopharmacol. 46, 31-47.

World Health Organization. 2008. "WHO Global Database: Stop the global epidemic of chronic disease." [Online]. Available: http://www.who.int/infobase/report.aspx?rid=126 [Cited 12 May 2008].

Zheng, Y.T., Chan, W.L., Chan, P., Huang, H., Tam, S.C., 2001. Enhancement of the antiherpetic effect of trichosanthin by acyclovir and interferon. FEBS Lett. 496, 139-142. 